Visit us - www.researchjournal.co.in DOI : 10.15740/HAS/IRJAES/7.2/178-181

International Research Journal of Agricultural Economics and Statistics

Volume 7 | Issue 2 | September, 2016 | 178-181 $\mathbf{a}$ e ISSN-2231-6434

\title{
Research Paper Study on variability in field experiments of wheat (Bhal and coastal zone) crop and yardstick
}

\section{G.N. MOTAKA, V.B. DARJI, D.J. PARMAR, A.D. KALOLA AND P.R. VAISHNAV}

See end of the paper for authors' affiliations

Correspondence to :

G.N. MOTAKA

Department of Agricultural

Statistics, Anand Agricultural

University, ANAND

(GUJARAT) INDIA

\section{Paper History :}

Received : 09.05.2016;

Revised : 18.07.2016;

Accepted : 16.08 .2016
Abstract : The data on C.V. per cent for wheat (Bhal and coastal zone) crop yield along with other details of 374 field experiments conducted during 1989-90 to 2014-15 at Agriculture Research Station, Anand Agricultural University, Arnej and Dhandhuka centre were collected and analyzed. The frequency distribution tables were prepared for various experimental factors. The upper fiducial limits (the yardstick) of C.V. per cent at 95 per cent confidence based on non- central ' $t$ ' distribution were worked out for accepting the results of wheat (Bhal and coastal zone) crop experiments which emerged as 15 per cent.

KEY WordS : CV per cent, Fiducial limit, Plot size, Non-central t distribution, Experimental variability

How To Cite This PAPer : Motaka, G. N., Darji, V.B., Parmar, D.J., Kalola, A.D. and Vaishnav, P.R. (2016). Study on variability in field experiments of wheat (Bhal and coastal zone) crop and yardstick. Internat. Res. J. Agric. Eco. \& Stat., 7 (2) : 178-181, DOI : 10.15740/HAS/IRJAES/7.2/178-181. 